\title{
Prognostic biomarkers in squamous cell carcinoma of the anus: a systematic review
}

\author{
T Lampejo*,', D Kavanagh', J Clark', R Goldin², M Osborn², P Ziprin' and S Cleator ${ }^{3}$ \\ 'Department of Biosurgery and Surgical Technology, Imperial College London, St Mary's Hospital, Praed Street, London, W2 INY, UK; ${ }^{2}$ Department of \\ Pathology, Imperial College London, St Mary's Hospital, Praed Street, London, W2 INY, UK; ${ }^{3}$ Department of Oncology, Imperial College London, St Mary's \\ Hospital, Praed Street, London, W2 INY, UK
}

BACKGROUND: Recent decades have seen combination chemoradiotherapy become the standard treatment for anal squamous cell carcinoma (SCC). However, the burden of this disease continues to rise, with only $10 \%$ of patients with metastatic disease surviving $>2$ years. Further insight into tumour characteristics and molecular biology may identify novel therapeutic targets. This systematic review examines current prognostic markers in SCC of the anus.

METHODS: An extensive literature search was performed to identify studies reporting on biomarkers in anal cancer in the context of clinical outcome following treatment primarily with chemoradiotherapy.

RESULTS: In all, 2 I studies were included. A total of 29 biomarkers were studied belonging to 9 different functional classes. Of these biomarkers, 13 were found to have an association with outcome in at least one study. The tumour-suppressor genes p53 and p2 I were the only markers shown to be of prognostic value in more than one study.

CONCLUSIONS: An array of biomarkers have been identified that correlate with survival following chemoradiotherapy in anal cancer. However, investigators are yet to identify a biomarker that has the ability to consistently predict outcome in this disease. Further studies are needed to elucidate whether these candidate biomarkers demonstrate their optimum value when they serve as targets for new therapeutic strategies.

British Journal of Cancer (2010) 1 03, 1858-1869. doi:10.1038/sj.bjc.6605984 www.bjcancer.com

Published online 9 November 2010

(C) 2010 Cancer Research UK

Keywords: prognosis; biomarker; molecular marker; anal carcinoma

Anal cancer is a disease whose incidence has risen markedly in several parts of the world including Europe and the United States (Rousseau et al, 2005). Of notable concern is the significant impact of this disease on the young male population, with incidence rates of up to 37 per 100000 in homosexual men (Place et al, 2001). Of men who have sex with men (MSM), 95\% are seropositive for the implicated viral pathogen, human papilloma virus (subtypes 16, 18, 32 and 34) (Palefsky et al, 2005). Also, 81\% of MSM have anal intraepithelial neoplasia (AIN; premalignant lesion) (Palefsky et al, 2005). HPV is associated with the proteins E6 and E7 that can silence important tumour-suppressor proteins in normal cells (Mammas et al, 2008). These proteins, namely p53 and Rb, normally exert apoptotic cellular effects to prevent disordered cell growth (Mammas et al, 2008). Removal of this growth restriction may lead to malignant transformation (Mammas et al, 2008). At the time of diagnosis, up to $50 \%$ of patients have locoregional disease with visceral metastases present in $10 \%$ of patients (UKCCCR Anal Cancer Trial Working Party, 1996; Rousseau et al, 2005). The most common sites are the liver and lungs (Rousseau et al, 2005).

In the past, the mainstay of treatment for anal carcinoma was abdominoperineal resection with formation of a permanent end

*Correspondence: Dr T Lampejo; E-mail: temi.lampejo02@imperial.ac.uk Received 10 September 2010; revised 7 October 2010; accepted 14 October 2010; published online 9 November 2010 colostomy. Over the last two decades, combined chemoradiotherapy pioneered in the 1970s by Nigro et al (1974) has become the standard of care with salvage abdominoperineal resection reserved for a small proportion of cases refractory to chemoradiotherapy (Place et al, 2001). Despite respectable treatment response rates in non-metastatic disease with overall survival rates of $60-75 \%$, only $10 \%$ of patients with distant metastases survive 2 years from the time of their diagnosis (Cummings, 2006; Das et al, 2008). Furthermore, it is evident that treatment response shows a degree of heterogeneity between individual patients within a specific stage category, suggesting a spectrum of chemoradiation sensitivity. Furthermore, the acute and long-term toxicity associated with standard chemoradiation schedules are considerable, and therefore predictors of response and novel therapeutic approaches are required to allow treatments to be tailored according to treatment sensitivity.

Clinical and pathological factors have been evaluated extensively with regard to outcomes in anal cancer. Clinicopathological parameters have not consistently enabled prediction of response to currently available treatment modalities. This had led to considerable interest in prognostic and predictive biomarkers as putative means to improving patient survival. A prognostic biomarker gives information regarding the patient's overall outcome, irrespective of the therapy received, whereas a predictive biomarker provides information about the effect of a specific therapeutic intervention (Oldenhuis et al, 2008). Molecular analysis may permit the tailoring of treatments to individual 
patients and help identify new therapeutic targets. Tyrosine kinases (TKs), which have an established role in malignant transformation of human cells, have served as major target in cancer treatment strategies such as imatinib, the BCR-ABL TK inhibitor used in the treatment of chronic myeloid leukaemia and GISTs (Madhusudan and Ganesan, 2004). In recent years, the epidermal growth factor receptor (EGFR - particularly HER-1 and HER-2) has been the most extensively investigated TKs and now forms a significant component of the ongoing research into molecular targeted cancer therapy. In non-small cell lung cancer, mutations in the TK domain of the EGFR have been shown to be associated with a high treatment response rate to the EGFR TK inhibitor erlotinib (Paz-Ares et al, 2006). Randomised trials in metastatic colorectal cancer have demonstrated that use of monoclonal antibodies directed against EGFR (HER-1), namely cetuximab and panitumumab, is associated with favourable outcomes in patients expressing the wild-type form of K-ras proto-oncogene (Siddiqui and Piperdi, 2009). Therefore, a search for putative predictive markers in anal cancer is warranted in order to explore whether these and other targeted treatments should be assessed in the setting of early and/or metastatic anal cancer.

The purpose of this systematic review was to evaluate the literature available to-date on biological and molecular prognostic factors in squamous cell carcinoma (SCC) of the anus.

\section{MATERIALS AND METHODS}

A systematic review was undertaken to identify the prognostic significance of biomarkers in anal cancer. During this process, reference to the AMSTAR measurement tool was made (Shea et al, 2007). This 11-component assessment tool was constructed to assess the methodological quality of systematic reviews. Although the reproducibility and construct validity of this tool is currently uncertain, preliminary findings suggest that AMSTAR has good construct validity and is a reliable tool for the methodological assessment of systematic reviews.

A comprehensive literature search was performed by two independent reviewers (TL and DK) using the PubMed, Web of Science, Embase and Google Scholar databases. This search was conducted up to 9 January 2010. The following keywords were used in various combinations: 'anal cancer', 'biomarkers', 'molecular markers', 'biological markers', 'prognosis' and 'clinical outcome' in addition to searching for individual biomarkers. Further relevant studies were identified by searching the references cited in identified publications and also by utilisation of the PubMed 'related articles' tool (Shalhoub et al, 2009).

No exclusions from the analysis were made based on the date of the publication or the type of the study. Articles not published in the English language were excluded. Studies were excluded because of the absence of (1) any data regarding clinical outcome or prognosis; (2) potentially extractable or a complete set of data considered necessary; (3) peer review status; and (4) the use of chemotherapy/radiotherapy as a primary treatment. Studies were also excluded if they referred to AIN rather than carcinoma.

In addition to patient demographics and tumour characteristics, outcomes of interest related to the study of potential biomarkers included the type of treatment received, tumour recurrence and patient relapse rates, disease-free survival (DFS), overall survival and mortality.

\section{RESULTS}

Using the search methods described above, a total of 179 articles were identified. Of these, 73 were initially excluded as they were not studies of anal cancer. Eight articles were not related to the study of biomarkers. A further 30 articles were also excluded by abstract review; 13 of these were review articles and 17 were case

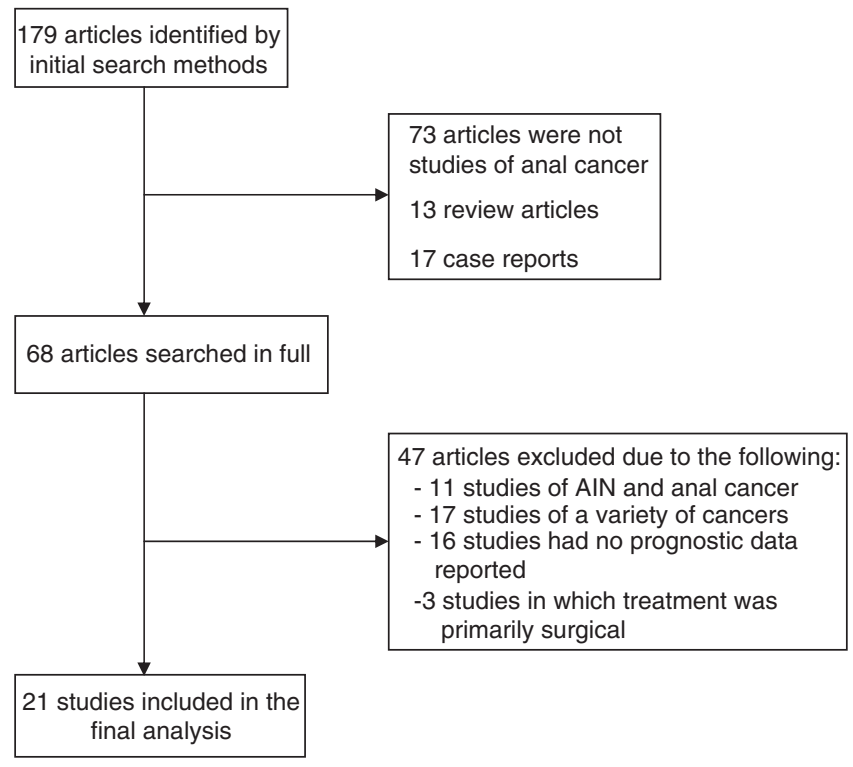

Figure I Flow diagram representing the selection process for the studies included in the final analysis.

reports. Of the remaining 68 references searched in full, 11 studies were excluded as they included the premalignant form, AIN, with no discrimination of results between the two disease groups. Another 17 studies were excluded as they combined data from human cancers of different anatomical locations (including anal carcinoma) with no breakdown of results for the various cancer types. Sixteen studies of biomarkers in anal cancer were excluded as correlation with prognosis was not assessed. Finally, three studies failed to meet the inclusion criteria, as the primary form of treatment in these studies was radical surgery rather than chemoradiation. Ultimately, 21 studies remained for full inclusion in this literature review (Figure 1) (Fontana et al, 1991; Tanum et al, 1992; Goldman et al, 1993; Holm and Tanum, 1996; Tanum and Holm, 1996; Allal et al, 1998, 2003, 2004; Grabenbauer et al, 1998; Bonin et al, 1999; Indinnimeo et al, 1999, 2000a, b, 2001; Wong et al, 1999; Holm et al, 2001; Le et al, 2005; Alvarez et al, 2006; Nilsson et al, 2006; Bruland et al, 2008; Ajani et al, 2009).

The 21 studies included in the analysis evaluated a number of different of biomarkers, which are discussed below and illustrated in Figure 2.

\section{Tumour-suppressor genes}

The primary role of tumour-suppressor genes is to regulate cell division, differentiation and apoptosis in order to prevent genetic damage that may lead to the development of cancerous cells. p53, $p 21, p 27, p 16$ and the retinoblastoma $(R B)$ gene are examples of such genes whose prognostic significance has been studied in anal carcinoma.

p53 The p53 gene located on chromosome 17p13.1 encodes a protein that has an important role in cell cycle regulation and apoptosis (Kastan et al, 1995). Additionally, wild-type p53 has been linked with cellular DNA damage repair and inhibition of angiogenesis (Vogelstein et al, 2000). This gene has been extensively studied in several human cancers, and mutations of this gene are considered to be the commonest genetic anomaly in human tumours (Wong et al, 1999). Evidence suggests that mutated p53 can lead to genomic instability and permit malignant transformation of previously non-cancerous cells (Finlay et al, 1989). 


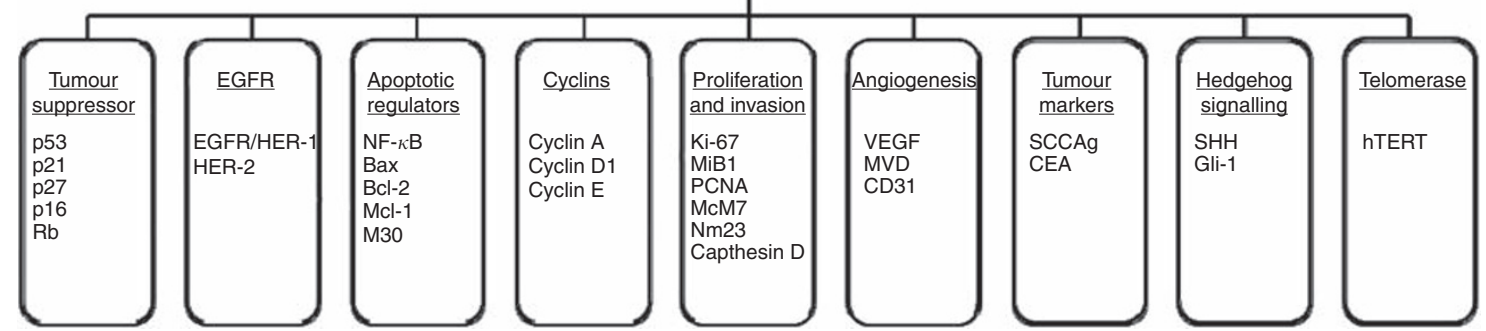

Figure 2 The classes and subclasses of biomarkers evaluated in the final 21 studies (highlighted in bold are the biomarkers that were associated with outcome in at least one study).

Table I Studies of tumour-suppressor genes (p53) in anal carcinoma

\begin{tabular}{|c|c|c|c|c|c|c|c|c|c|c|}
\hline Authors & Year & Biomarker & $\begin{array}{l}\text { Patients } \\
(n)^{\mathrm{a}}\end{array}$ & Method & $\begin{array}{l}\text { Radio } \pm \text { chemo- } \\
\text { therapy (n) }\end{array}$ & $\begin{array}{c}\text { Primary } \\
\text { surgical } \\
\text { treatment }(n)\end{array}$ & $\begin{array}{l}\text { Mean (median) } \\
\text { follow-up } \\
\text { period in } \\
\text { months }\end{array}$ & $\begin{array}{l}\text { Biomarker } \\
\text { +ve patients }\end{array}$ & $\begin{array}{l}\text { Survival } \\
\text { (biomarker } \\
\text { +ve vs -ve } \\
\text { patients) }\end{array}$ & $\begin{array}{l}\text { Correlation with } \\
\text { prognosis }\end{array}$ \\
\hline Bonin et al & 1999 & p53 & 64 & $\mathrm{IHC}$ & $\begin{array}{l}64 \text { chemo- } \\
\text { radiotherapy }\end{array}$ & 0 & (57) & $48 \%$ & 48 vs $33 \%$ DFS & $\begin{array}{l}\text { No prognostic significance } \\
\text { identified }\end{array}$ \\
\hline $\begin{array}{l}\text { Indinnimeo } \\
\text { et al }\end{array}$ & 1999 & p53 & 14 & $\mathrm{IHC}$ & Not reported & Not reported & 57.6 & $60 \%$ & 44 vs $40 \%$ DFS & $\begin{array}{l}\text { No prognostic significance } \\
\text { identified }\end{array}$ \\
\hline Allal et al & 2003 & p53 & 98 & $\mathrm{HHC}$ & $\begin{array}{l}47 \text { radiotherapy } \\
\text { alone } 5 \mathrm{I} \text { chemo- } \\
\text { radiotherapy }\end{array}$ & 0 & (124) & $43 \%$ & $\begin{array}{l}75 \text { vs } 55 \% \\
5 \text {-year DFS }\end{array}$ & $\begin{array}{l}\text { p53 expression associated } \\
\text { with reduced local tumour } \\
\text { control }(P=0.03) \text { and } \\
\text { reduced DFS }(0.003)\end{array}$ \\
\hline Le et $a l$ & 2005 & p53 & 21 & $\mathrm{IHC}$ & $\begin{array}{l}21 \text { chemo- } \\
\text { radiotherapy }\end{array}$ & 0 & Not reported & $100 \%$ & Not reported & $\begin{array}{l}\text { No prognostic significance } \\
\text { identified }\end{array}$ \\
\hline Nilsson et al & 2006 & p53 & 214 & $\mathrm{IHC}$ & Not reported & $\begin{array}{c}7 \text { local excision, } \\
6 \text { APR }\end{array}$ & Not reported & $50 \%$ & Not reported & $\begin{array}{l}\text { No prognostic significance } \\
\text { identified }\end{array}$ \\
\hline
\end{tabular}

Abbreviations: $A P R=$ abdominoperineal resection; DFS = disease-free survival; $\mathrm{IHC}=$ immunohistochemistry; $\mathrm{Rb}=$ retinoblastoma; RR $=$ relative risk. ${ }^{\mathrm{a}} \mathrm{Patients}$ included in final biomarker analysis. ' In studies where patients have been differentiated by the presence or absence of tumour biomarker overexpression, overexpression is considered as biomarker positive.

Eight studies evaluated the prognostic significance of $\mathrm{p} 53$ in anal carcinoma (Table 1) (Tanum and Holm, 1996; Bonin et al, 1999; Indinnimeo et al, 1999; Wong et al, 1999; Allal et al, 2003; Le et al, 2005; Nilsson et al, 2006; Ajani et al, 2009). Immunohistochemistry was utilised in all studies to assess nuclear p53 status in anal carcinoma paraffin-embedded specimens. Wild-type p53 protein has a relatively short half-life and is less readily detectable by immunohistochemical staining. However, mutated p53 typically undergoes a conformational change that stabilises the protein, resulting in nuclear accumulation and therefore positive staining (Neal et al, 2006). In these studies, p53 was considered to be overexpressed if $>5 \%$ of tumour cells stained positive for nuclear p53. The proportion of patients with anal carcinoma overexpressing p53 ranged from 34 to $100 \%$.

Two studies demonstrated a significant correlation between p53 status and clinical outcome in anal carcinoma. Allal et al (2003) found through multivariate analysis that patients with p53-positive tumours had a lower rate of locoregional control (RR, 0.38;
$P=0.03)$ and shorter DFS (RR, 0.29; $P=0.003)$. Similarly, Wong et al (1999) showed that p53 overexpression was an independent adverse marker for DFS in patients with anal carcinoma treated with combined chemoradiotherapy $(P=0.01)$. Another study consisting of 64 patients reported a trend using univariate analysis towards higher locoregional failure rates following chemoradiotherapy in patients with mutant p53 compared with those with the wild-type form ( $48 v s 27 \%, P=0.14$ ) (Bonin et al, 1999). However, this finding did not reach statistical significance and no further correlation was seen with either DFS or overall survival (Bonin et al, 1999). The five remaining studies examining p53 did not identify any correlation between its overexpression and clinicopathological parameters or survival (Tanum and Holm, 1996; Indinnimeo et al, 1999; Le et al, 2005; Nilsson et al, 2006; Ajani et al, 2009).

p21 Activation of the $\mathrm{p} 21$ protein, a cyclin-dependent kinase (CDK) inhibitor, results in cell cycle arrest at the G1- to S-phase transition in mammals (Harper et al, 1993). Its effector functions 
Table 2 Studies of tumour suppressor-genes in anal carcinoma

\begin{tabular}{|c|c|c|c|c|c|c|c|c|c|c|}
\hline Authors & Year & Biomarker & $\begin{array}{l}\text { Patients } \\
(n)^{\mathrm{a}}\end{array}$ & Method & $\begin{array}{l}\text { Radio } \pm \text { chemo- } \\
\text { therapy (n) }\end{array}$ & $\begin{array}{c}\text { Primary } \\
\text { surgical } \\
\text { treatment }(n)\end{array}$ & $\begin{array}{c}\text { Mean (median) } \\
\text { follow-up } \\
\text { period } \\
\text { in months }\end{array}$ & $\begin{array}{l}\text { Biomarker } \\
\text { +ve patients }\end{array}$ & $\begin{array}{l}\text { Survival } \\
\text { (biomarker } \\
\text { +ve vs -ve } \\
\text { patients) }\end{array}$ & $\begin{array}{l}\text { Correlation with } \\
\text { prognosis }\end{array}$ \\
\hline Holm et al & 2001 & p21 & 94 & $\mathrm{IHC}$ & $\begin{array}{l}94 \text { chemo- } \\
\text { radiotherapy }\end{array}$ & 0 & 60 & $71 \%$ & Not reported & $\begin{array}{l}\text { Lack of } p 21 \text { expression } \\
\text { associated with reduced } \\
\text { overall survival }(P=0.013)\end{array}$ \\
\hline Allal et al & 2004 & p21 & 98 & $\mathrm{HC}$ & $\begin{array}{l}47 \text { radiotherapy } \\
\text { alone } 5 \text { I chemo- } \\
\text { radiotherapy }\end{array}$ & 0 & $(124)$ & $65 \%$ & $\begin{array}{l}66 \text { vs } 59 \% \\
5 \text {-year DFS }\end{array}$ & $\begin{array}{l}\text { No prognostic significance } \\
\text { identified }\end{array}$ \\
\hline Nilsson et al & 2006 & p21 & 215 & $\mathrm{IHC}$ & Not reported & $\begin{array}{l}7 \text { local excision, } \\
6 \text { APR }\end{array}$ & Not reported & $69 \%$ & $\begin{array}{l}71 \text { vs } 62 \% 5 \text { year } \\
\text { overall survival }\end{array}$ & $\begin{array}{l}\text { Absence of } \mathrm{p} 2 \mathrm{I} \text { associated } \\
\text { with an increased locoregional } \\
\text { failure rate }(P<0.05)\end{array}$ \\
\hline Holm et al & 2001 & p27 & 94 & $\mathrm{IHC}$ & $\begin{array}{l}94 \text { chemo- } \\
\text { radiotherapy }\end{array}$ & 0 & 60 & $75 \%$ & Not reported & $\begin{array}{l}\text { No prognostic significance } \\
\text { identified }\end{array}$ \\
\hline Bruland et al & 2008 & pl6 & 55 & $\mathrm{HC}$ & $\begin{array}{l}9 \text { radiotherapy } \\
\text { alone } 46 \text { chemo- } \\
\text { radiotherapy }\end{array}$ & 0 & 86.4 & Not reported & Not reported & $\begin{array}{l}\text { No prognostic significance } \\
\text { identified }\end{array}$ \\
\hline Ajani et al & 2009 & pl6 & 30 & $\mathrm{HC}$ & $\begin{array}{l}30 \text { chemo- } \\
\text { radiotherapy }\end{array}$ & 0 & Not reported & Not reported & $\begin{array}{l}R R=0.81 \\
\text { for DFS }\end{array}$ & $\begin{array}{l}\text { No prognostic significance } \\
\text { identified }\end{array}$ \\
\hline $\begin{array}{l}\text { Tanum and } \\
\text { Holm }\end{array}$ & 1996 & $\mathrm{Rb}$ & 97 & $\mathrm{HC}$ & $\begin{array}{l}97 \text { chemo- } \\
\text { radiotherapy }\end{array}$ & 0 & $(60)$ & $95 \%$ & Not reported & $\begin{array}{l}\text { No prognostic significance } \\
\text { identified }\end{array}$ \\
\hline
\end{tabular}

Abbreviations: $A P R=$ abdominoperineal resection; DFS = disease-free survival; $\Vdash H C=$ immunohistochemistry; $R b=$ retinoblastoma; $R R=$ relative risk. ${ }^{\mathrm{a}} \mathrm{Patients}$ included in final biomarker analysis. ${ }^{b}$ In studies where patients have been differentiated by the presence or absence of tumour biomarker overexpression, overexpression is considered as biomarker positive.

are predominantly induced by $\mathrm{p} 53$ and it is considered to be a mediator of the tumour-suppressor activity of p53 (el-Deiry et al, 1993). However, it also appears to function via mechanisms independent of the $p 53$ gene in response to cellular DNA damage (Roninson, 2002). Underexpression of p21 has been associated with poor prognostic outcome in various human cancers including SCC of the lung (Komiya et al, 1997).

Three studies have assessed the relationship between p21 and prognosis in anal carcinoma using immunohistochemistry to determine the level of p21 expression (Table 2) (Holm et al, 2001; Allal et al, 2004; Nilsson et al, 2006). The study by Holm et al (2001) included 94 patients with anal carcinoma. They reported high p21 expression in $71 \%$ of patients with anal carcinoma ( vs $10 \%$ positivity in negative controls of normal anal squamous epithelium). Univariate analysis demonstrated a significant association between lack of p21 immunoreactivity and poorly differentiated carcinomas $(P=0.004)$ and shorter overall survival $(P=0.013)$ (Holm et al, 2001). No significant correlation was seen between p21 expression and tumour stage or presence of nodal metastases in this study (Holm et al, 2001). Nilsson et al (2006) and Allal et al (2004) reported high p21 expression in 69 and $65 \%$ of anal cancers, respectively. Both studies demonstrated a trend towards shorter survival in p21-negative tumours, but statistical significance was not reached $(P=0.08$ and $P=0.1$, respectively). Conversely, multivariate analysis by Nilsson et al (2006) found that patients with tumours underexpressing p21 had a significantly higher locoregional failure rate $(P<0.05)$.

p27 The p27 protein is a member of the CDK inhibitor family that blocks phosphorylation of the Rb protein, thus inhibiting cell growth and proliferation (Coate et al, 2009). Like the p21 protein, p27 is involved in cell cycle control at the G1- to S-phase transition (Coate et al, 2009). A Norwegian study assessed the prognostic significance of p27 using immunohistochemistry in 94 patients with anal carcinoma (Table 2) (Holm et al, 2001). Nuclear p27 staining was detected in $75 \%$ of cases of anal carcinoma compared with $100 \%$ of samples of normal anal squamous epithelium (Holm et al, 2001). No correlation was found between p27 expression and tumour stage, lymph node involvement or overall survival (Holm et al, 2001). The investigators did however find that reduced p27 expression was associated with moderate/highly differentiated carcinomas (Holm et al, 2001). p16 The p16 protein, also known as cyclin-dependent kinase inhibitor 2A (CDKN2A), specifically targets and inhibits the activity of CDK 4 and CDK 6, both of which are involved in cell proliferation (Bruland et al, 2008). Studies of p16 have demonstrated a potential prognostic role for this biomarker in oropharyngeal SCC (Shi et al, 2009). Two recent studies consisting of 55 and 30 patients, respectively, investigated the possible role of p53 in predicting outcome in anal cancer (Table 2) (Bruland et al, 2008; Ajani et al, 2009). Neither study identified any association between p16 protein expression and clinical outcome or treatment response (Bruland et al, 2008; Ajani et al, 2009).

The RB gene The $R B$ gene, a tumour-suppressor gene originally found to be mutated in the rare paediatric malignancy, retinoblastoma, encodes a nuclear protein involved in cell differentiation, proliferation and apoptosis (Du and Searle, 2009). $R B$ gene mutations leading to loss of its tumour-suppressor function has been identified in a variety of human malignancies (Bourgo et al, 2009; Du and Searle, 2009). One study of the $R B$ gene in anal carcinomas found no significant rearrangement or loss of the RB locus in malignant (or benign) tissue (Crook et al, 1991).

Tanum and Holm (1996) evaluated 97 patients treated with chemoradiotherapy for anal carcinoma (Table 2). Of the pretreatment tumour specimens, $95 \%$ stained positive for the $\mathrm{Rb}$ protein. No relationship was identified between protein expression and the clinical course of the disease.

\section{EGFR}

Four transmembrane TK proteins (HER-1 to HER-4) make up the EGFR family of receptors that regulate cellular proliferation, angiogenesis, apoptosis and migration via binding of specific ligands (Neal et al, 2006; Coate et al, 2009). The intimate association between the EGFR overexpression and cancer development has served as a platform for the introduction of newer therapies targeting these receptors. This is therapeutically achieved through direct inhibition of TK or through antibody-mediated targeting of receptors. Monoclonal antibodies directly bind to the external domain of these TK receptors. Traztuzumab (Herceptin), a monoclonal antibody against the HER-2 receptor, has been widely established in breast cancer patients overexpressing HER-2 with significantly improved survival rates reported in these 
Table 3 Studies of the EGFR family in anal carcinoma

\begin{tabular}{|c|c|c|c|c|c|c|c|c|c|c|}
\hline Authors & Year & Biomarker & $\begin{array}{l}\text { Patients } \\
\qquad(n)^{\mathrm{a}}\end{array}$ & Method & $\begin{array}{l}\text { Radio } \pm \text { chemo- } \\
\text { therapy }(n)\end{array}$ & $\begin{array}{c}\text { Primary } \\
\text { surgical } \\
\text { treatment }(n)\end{array}$ & $\begin{array}{l}\text { Mean (median) } \\
\text { follow-up period } \\
\text { in months }\end{array}$ & $\begin{array}{c}\text { Biomarker } \\
\text { +ve patients }\end{array}$ & $\begin{array}{l}\text { Survival (biomarker } \\
\text { +ve vs - ve patients) }\end{array}$ & $\begin{array}{l}\text { Correlation with } \\
\text { prognosis }\end{array}$ \\
\hline $\begin{array}{l}\text { Tanum and } \\
\text { Holm }\end{array}$ & 1996 & $\begin{array}{c}\text { c-erb } \\
\text { B-2/HER-2 }\end{array}$ & 97 & $\mathbb{H C}$ & $\begin{array}{l}97 \text { chemo- } \\
\text { radiotherapy }\end{array}$ & 0 & 60 & 0 & Not reported & $\begin{array}{l}\text { No prognostic significance } \\
\text { identified }\end{array}$ \\
\hline Le et al & 2005 & HER-2 & 21 & $\mathrm{HC}$ & $\begin{array}{l}21 \text { chemo- } \\
\text { radiotherapy }\end{array}$ & 0 & Not reported & 0 & Not reported & $\begin{array}{l}\text { No prognostic significance } \\
\text { identified }\end{array}$ \\
\hline Le et al & 2005 & EGFR/HER-I & 21 & $\mathrm{HC}$ & $\begin{array}{l}21 \text { chemo- } \\
\text { radiotherapy }\end{array}$ & 0 & Not reported & $100 \%$ & Not reported & $\begin{array}{l}\text { High EGFR expression } \\
\text { seen in all } 21 \text { specimens }\end{array}$ \\
\hline Alvarez et al & 2006 & EGFR/HER-I & 38 & $\begin{array}{l}\mathrm{HC}_{\mathrm{H}} \text { and } \\
\mathrm{FISH}\end{array}$ & $\begin{array}{l}38 \text { chemo- } \\
\text { radiotherapy }\end{array}$ & 0 & 22.6 & $55 \%$ & Not reported & $\begin{array}{l}\text { No prognostic significance } \\
\text { identified }\end{array}$ \\
\hline Ajani et al & 2009 & EGFR/HER-I & 30 & $\mathrm{HC}$ & $\begin{array}{l}30 \text { chemo- } \\
\text { radiotherapy }\end{array}$ & 0 & Not reported & $87 \%$ & $\mathrm{RR}=0.40$ for $\mathrm{DFS}$ & $\begin{array}{l}\text { No prognostic significance } \\
\text { identified }\end{array}$ \\
\hline
\end{tabular}

Abbreviations: EGFR = epidermal growth factor receptor; $I \mathrm{HC}=$ immunohistochemistry; FISH = fluorescent in situ hybridisation; RR = relative risk. ${ }^{\mathrm{a}} \mathrm{Patients}$ included in final biomarker analysis. ${ }^{b}$ In studies where patients have been differentiated by the presence or absence of tumour biomarker overexpression, overexpression is considered as biomarker positive.

Table 4 Studies of apoptotic regulators in anal carcinoma

\begin{tabular}{|c|c|c|c|c|c|c|c|c|c|c|}
\hline Authors & Year & $\begin{array}{l}\text { Bio- } \\
\text { marker }\end{array}$ & $\begin{array}{l}\text { Patients } \\
\qquad(n)^{\mathrm{a}}\end{array}$ & Method & $\begin{array}{l}\text { Radio } \pm \text { chemo- } \\
\text { therapy }(n)\end{array}$ & $\begin{array}{l}\text { Primary } \\
\text { surgical } \\
\text { treatment }(n)\end{array}$ & $\begin{array}{l}\text { Mean (median) } \\
\text { follow-up period } \\
\text { in months }\end{array}$ & $\begin{array}{c}\text { Biomarker } \\
+ \text { ve patients }\end{array}$ & $\begin{array}{l}\text { Survival } \\
\text { (biomarker } \\
\text { +ve vs - ve } \\
\text { patients) }\end{array}$ & Correlation with prognosis \\
\hline Ajani et al & 2009 & $\mathrm{NF}-\kappa \mathrm{B}$ & 30 & $\amalg \mathrm{HC}$ & 30 chemoradiotherapy & 0 & Not reported & Not reported & $\begin{array}{l}R R=1.05 \\
\text { for DFS }\end{array}$ & $\begin{array}{l}\text { Higher levels of NF- } \kappa \text { B associated } \\
\text { with shorter DFS }(P=0.002)\end{array}$ \\
\hline Allal et al & 2003 & $\operatorname{Bax}$ & 98 & $\mathrm{IHC}$ & $\begin{array}{l}47 \text { radiotherapy } \\
\text { alone } \\
51 \text { chemoradiotherapy }\end{array}$ & 0 & $(124)$ & $29 \%$ & $\begin{array}{l}61 \text { vs } 65 \% \\
5 \text {-year DFS }\end{array}$ & $\begin{array}{l}\text { No prognostic significance } \\
\text { identified }\end{array}$ \\
\hline Allal et al & 2003 & $\mathrm{Bcl}-2$ & 98 & $\Vdash H C$ & $\begin{array}{l}47 \text { radiotherapy } \\
\text { alone } \\
51 \text { chemoradiotherapy }\end{array}$ & 0 & $(124)$ & $58 \%$ & $\begin{array}{l}56 \text { vs } 75 \% \\
5 \text {-year DFS }\end{array}$ & $\begin{array}{l}\text { Bcl-2 expression associated with } \\
\text { improved local tumour control } \\
(P=0.0015) \text { and DFS }(P=0.00 \mathrm{I})\end{array}$ \\
\hline Le et al & 2005 & $\mathrm{Bcl}-2$ & 21 & $\amalg \mathrm{HC}$ & 21 chemoradiotherapy & 0 & Not reported & $24 \%$ & Not reported & $\begin{array}{l}\text { No prognostic significance } \\
\text { identified }\end{array}$ \\
\hline Ajani et al & 2009 & $\mathrm{Bcl}-2$ & 30 & $\amalg \mathrm{HC}$ & 30 chemoradiotherapy & 0 & Not reported & Not reported & $\begin{array}{l}R R=0.90 \\
\text { for DFS }\end{array}$ & $\begin{array}{l}\text { No prognostic significance } \\
\text { identified }\end{array}$ \\
\hline Allal et al & 2003 & Mcl-I & 98 & $\amalg \mathrm{HC}$ & $\begin{array}{l}47 \text { radiotherapy } \\
\text { alone } \\
51 \text { chemoradiotherapy }\end{array}$ & 0 & $(124)$ & $36 \%$ & $\begin{array}{l}60 \text { vs } 66 \% \\
5 \text {-year DFS }\end{array}$ & $\begin{array}{l}\text { No prognostic significance } \\
\text { identified }\end{array}$ \\
\hline Allal et al & 2003 & M30 & 98 & $\amalg \mathrm{HC}$ & $\begin{array}{l}47 \text { radiotherapy } \\
\text { alone } \\
51 \text { chemoradiotherapy }\end{array}$ & 0 & $(124)$ & $88 \%$ & $\begin{array}{l}67 \text { vs } 37 \% \\
5 \text {-year DFS }\end{array}$ & $\begin{array}{l}\text { Presence of M30 associated with } \\
\text { lower local control }(P=0.034) \\
\text { and lower DFS }(P=0.03)\end{array}$ \\
\hline
\end{tabular}

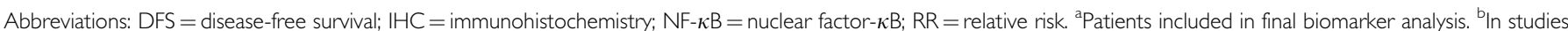
where patients have been differentiated by the presence or absence of tumour biomarker overexpression, overexpression is considered as biomarker positive.

patients (Treish et al, 2000). As previously mentioned, the TK inhibitor erlotinib has been successfully used in the treatment of non-small cell lung cancer (Paz-Ares et al, 2006).

Tanum and Holm (1996) studied HER-2 protein expression in 97 patients with anal carcinoma who received chemoradiotherapy. HER-2 protein expression was undetectable (Table 3) (Tanum and Holm, 1996). Similarly, in a Canadian study of 21 patients with anal cancer, all samples were negative for HER-2 (Le et al, 2005). However, this study found that EGFR (HER-1) was strongly expressed in $100 \%$ of patients (Le et al, 2005). Ajani et al (2009) also performed immunohistochemical analysis of EGFR and reported expression in $86 \%$ of patients with anal cancer, but no significant correlation was observed between the degree of EGFR staining and DFS. One study detected EGFR using immunohistochemistry in 55\% of anal SCCs. They also performed fluorescent in situ hybridisation (FISH) to assess EGFR gene copy numbers (Alvarez et al, 2006). There was no correlation between EGFR status and clinicopathological parameters. Furthermore, there was a lack of concordance between the two detection techniques (Alvarez et al, 2006).

\section{Regulators of apoptosis}

Apoptosis and the genes that regulate it exert a profound effect on the malignant phenotype in mammalian cells (Lowe and Lin, 2000)
(Table 4). Mutations in genes encoding these apoptotic regulatory proteins can lead to tumour initiation, progression or metastasis (Lowe and Lin, 2000).

Nuclear factor $-\kappa B(N F-\kappa B)$ The nuclear transcription factor NF- $\kappa \mathrm{B}$ has been shown to prevent apoptosis through direct inhibitory mechanisms as well as indirectly by blocking mitochondria-mediated apoptosis through neutralisation of reactive oxygen species (Naugler and Karin, 2008). Moreover, poor chemotherapeutic responses have been attributed to NF- $\kappa \mathrm{B}$-induced resistance to apoptosis (Naugler and Karin, 2008).

A recent study (Ajani et al, 2009) of 30 patients with anal cancer treated with chemoradiotherapy reported that NF- $\kappa \mathrm{B}$ was an independent predictor of DFS. Multivariate analysis revealed that patients with higher NF- $\kappa$ B levels, detected by immunohistochemistry, had shorter DFS $(P=0.002)$ (Ajani et al, 2009).

Bcl-2, Bax and M30 The Bcl-2 family consists of at least 15 protein members including $\mathrm{Bcl}-2$ and $\mathrm{Mcl}-1$ that promote cell survival by inhibiting apoptosis. They are upregulated in certain tumour types (Lowe and Lin, 2000). Conversely, the Bax protein is a proapoptotic molecule that functions as a downstream component of the p53 pathway. It has been shown to be 
Table 5 Studies of cyclins in anal carcinoma

\begin{tabular}{|c|c|c|c|c|c|c|c|c|c|c|}
\hline Authors & Year & $\begin{array}{l}\text { Bio- } \\
\text { marker }\end{array}$ & $\begin{array}{l}\text { Patients } \\
(n)^{\mathrm{a}}\end{array}$ & Method & $\begin{array}{l}\text { Radio } \pm \text { chemo- } \\
\text { therapy (n) }\end{array}$ & $\begin{array}{l}\text { Primary } \\
\text { surgical } \\
\text { treatment }(n)\end{array}$ & $\begin{array}{l}\text { Mean (median) } \\
\text { follow-up } \\
\text { period in } \\
\text { months }\end{array}$ & $\begin{array}{c}\text { Biomarker } \\
\text { +ve patients }\end{array}$ & $\begin{array}{l}\text { Survival } \\
\text { (biomarker } \\
\text { +ve vs -ve } \\
\text { patients) }\end{array}$ & Correlation with prognosis \\
\hline Nilsson et al & 2006 & Cyclin A & 215 & $\mathrm{IHC}$ & Not reported & $\begin{array}{l}7 \text { local excision, } \\
6 \text { APR }\end{array}$ & Not reported & $51 \%$ & $\begin{array}{l}77 \text { vs } 59 \% 5 \text {-year } \\
\text { overall survival }\end{array}$ & $\begin{array}{l}\text { High cyclin A expression associated } \\
\text { with improved overall }(P=0.005) \\
\text { and DFS }(P=0.009)\end{array}$ \\
\hline Allal et al & 2004 & Cyclin DI & 98 & $\mathrm{IHC}$ & $\begin{array}{l}47 \text { radiotherapy } \\
\text { alone } \\
51 \text { chemoradiotherapy }\end{array}$ & 0 & $(124)$ & $34 \%$ & $\begin{array}{l}57 \text { vs } 67 \% \\
5 \text {-year DFS }\end{array}$ & No prognostic significance identified \\
\hline $\begin{array}{l}\text { Le et al } \\
\text { Allal et al }\end{array}$ & $\begin{array}{l}2005 \\
2004\end{array}$ & $\begin{array}{l}\text { Cyclin DI } \\
\text { Cyclin E }\end{array}$ & $\begin{array}{l}21 \\
98\end{array}$ & $\begin{array}{l}\mathrm{HC} \\
\mathrm{HC}\end{array}$ & $\begin{array}{l}21 \text { chemoradiotherapy } \\
47 \text { radiotherapy } \\
\text { alone } \\
51 \text { chemoradiotherapy }\end{array}$ & $\begin{array}{l}0 \\
0\end{array}$ & $\begin{array}{l}\text { Not reported } \\
\quad(124)\end{array}$ & $\begin{array}{l}33 \% \\
51 \%\end{array}$ & $\begin{array}{l}\text { Not reported } \\
61 \text { vs } 67 \% \\
5 \text {-year DFS }\end{array}$ & $\begin{array}{l}\text { No prognostic significance identified } \\
\text { No prognostic significance identified }\end{array}$ \\
\hline
\end{tabular}

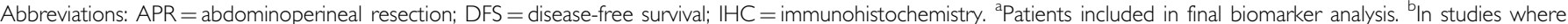
patients have been differentiated by the presence or absence of tumour biomarker overexpression, overexpression is considered as biomarker positive.

mutationally inactivated in patients with SCC of the oesophagus and this genotype correlated with poorer survival rates (Sturm et $a l, 2001)$. The M30 protein is a monoclonal antibody that recognises a neoepitope of cytokeratin 18 produced during apoptosis, thus serving as a marker of spontaneous apoptosis (Carr, 2000).

Allal et al (2003) assessed the prognostic significance of apoptotic regulatory proteins in anal carcinoma The proportion of tumours expressing Mcl-1 and Bcl-2 were 64 and 42\%, respectively (Allal et al, 2003). Although Mcl-1 was found to have no prognostic significance, lack of Bcl-2 expression was an independent negative factor for local control (RR 4.66, $P=0.0015$ ) and also for DFS (RR 4.11, $P=0.001$ ) (Allal et al, 2003). In the same study, Bax and M30 expression was 42 and $12 \%$, respectively, but neither showed correlation with clinical outcome in the 98 patients studied (Allal et al, 2003).

Two other studies have investigated Bcl-2 in patients with anal cancer, but there was no significant association with survival (Le et al, 2005; Ajani et al, 2009).

\section{Cyclins}

Cyclins are a family of proteins that function in conjunction with CDKs to positively regulate specific cell cycle transition points (Bartek and Lukas, 2001). They have been studied extensively as regulators of cell cycle progression. The prognostic significance of three members of the cyclin family (A, D1 and E) has been studied in anal carcinoma (Table 5) (Allal et al, 2004; Le et al, 2005; Nilsson et al, 2006). All three cyclins govern cell cycle progression at the G1/S transition point, and cyclin A additionally exhibits regulatory control at the G2/M transition point (Pagano et al, 1992). Nilsson et al (2006) studied 215 patients with anal SCC and identified high cyclin A expression in $51 \%$ of these patients. This was significantly associated with better tumour-specific (81 vs 64\%, $P=0.009$ ) and overall survival (77 vs 59\%, $P=0.005)$ when compared with tumours with low cyclin A expression (Nilsson et al, 2006). Furthermore, a lower rate of isolated locoregional failure was seen in patients with tumours expressing high levels of cyclin A $(P<0.05)$ (Nilsson et al, 2006). Uni- and multi-variate analyses revealed that cyclin A was an independent predictive marker of survival (hazard ratio $0.54,95 \% \mathrm{CI}$ ). In the two studies of cyclin D1 and one study of cyclin E in patients with anal cancer treated with radiotherapy \pm chemotherapy, pretreatment tumour levels of these proteins were found to have no association with patient outcome (Allal et al, 2004; Le et al, 2005).

\section{Markers of proliferation, invasion and metastasis}

$\mathrm{Ki}-67$ and MiB1 Ki-67 protein is a nuclear antigen expressed in proliferating cells. It can be detected within cells in all phases of the cell cycle except in $\mathrm{G}_{0}$ (Gerdes et al, 1983). This nuclear antigen expresses an epitope that is recognised by a murine monoclonal antibody known as MiB1, and therefore the number of Ki-67/ MiB1-positive nuclei (termed the $\mathrm{Ki}-67 / \mathrm{MiB} 1$ index) can be used as a marker of cellular proliferation in paraffin-embedded tumour specimens.

Four studies have investigated the association between cellular proliferation in anal carcinoma as determined by the Ki-67/MiB1 index and clinical outcome (Table 6) (Allal et al, 1998; Grabenbauer et al, 1998; Indinnimeo et al, 2000b; Ajani et al, 2009). In the most recent of these studies by Ajani et al (2009), multivariate analysis identified $\mathrm{Ki}-67$ as an independent predictor of DFS; a higher Ki-67 index correlated with longer DFS in patients treated with chemoradiotherapy $(P=0.03)$. These findings are consistent with an earlier study identifying improved colostomyfree survival (90 vs 50\%, $P=0.04$ ) in patients with tumours of higher proliferative potential as measured by the MiB1 index (Grabenbauer et al, 1998). Two others studies found no association between proliferative activity and patient survival in anal cancer (Allal et al, 1998; Indinnimeo et al, 2000b). One study did however report a significant correlation between $\mathrm{Ki}-67$ index and depth of tumour invasion $(P<0.05)$ and lymph node involvement $(P<0.05)$ (Indinnimeo et al, 2000b).

These findings support a predictive role for $\mathrm{Ki}-67 / \mathrm{MiB} 1$ in the prognosis of anal cancer patients treated with chemoradiotherapy (Grabenbauer et al, 1998; Ajani et al, 2009). In these studies, high $\mathrm{Ki}-67 / \mathrm{MiB} 1$ positivity correlated with improved survival that may be related to heightened responses to antiproliferative chemotherapeutic agents. It is noteworthy that in the two studies where no prognostic significance was found, there were a cohort of patients who were not treated with chemotherapy but received radiotherapy (with or without local excision) (Allal et al, 1998; Indinnimeo et al, 2000b).

Proliferating cell nuclear antigen (PCNA) PCNA is a nuclear protein associated with the late $G_{1}, S$ and early $G_{2}$ phases of the cell cycle (Shin et al, 1994). It has a vital role in DNA synthesis and initiation of cellular proliferation. A single study has assessed the prognostic significance of PCNA in anal carcinoma, in which immunohistochemistry was used to analyse tumour samples obtained from 62 patients (Table 6) (Grabenbauer et al, 1998). There was no correlation with clinical outcome, and there have been no novel data identifying the prognostic value of PCNA in anal SCC.

Non-metastatic protein 23 (Nm23) Studies of the $\mathrm{nm} 23$ protein both in vitro and in vivo have revealed a potential role in suppressing tumour metastasis through mechanisms that may be dependent on its nucleoside diphosphate kinase (NDPK) activity (MacDonald et al, 1995). Holm and Tanum (1996) studied nm23 expression using immunohistochemical analysis in 96 patients with anal carcinoma (Table 6). Of these specimens, 
Table 6 Studies of markers of proliferation, invasion and metastasis in anal carcinoma

\begin{tabular}{|c|c|c|c|c|c|c|c|c|c|c|}
\hline Authors & Year & $\begin{array}{l}\text { Bio- } \\
\text { marker }\end{array}$ & $\begin{array}{l}\text { Patients } \\
(n)^{\mathbf{a}}\end{array}$ & Method & $\begin{array}{l}\text { Radio } \pm \text { chemo- } \\
\text { therapy }(n)\end{array}$ & $\begin{array}{l}\text { Primary } \\
\text { surgical } \\
\text { treatment }(n)\end{array}$ & $\begin{array}{l}\text { Mean (median) } \\
\text { follow-up } \\
\text { period in } \\
\text { months }\end{array}$ & $\begin{array}{c}\text { Biomarker } \\
+ \text { ve patients }\end{array}$ & $\begin{array}{l}\text { Survival } \\
\text { (biomarker } \\
\text { +ve vs - ve } \\
\text { patients) }\end{array}$ & Correlation with prognosis \\
\hline Allal et al & 1998 & $\mathrm{MiBI}$ & 55 & $\Vdash H C$ & $\begin{array}{l}31 \text { chemo- } \\
\text { radiotherapy } \\
\text { I } 4 \text { radiotherapy only }\end{array}$ & 0 & (94) & $41 \%$ & $\begin{array}{l}59 \text { vs } 67 \% \\
5 \text {-year DFS }\end{array}$ & $\begin{array}{l}\text { No prognostic significance } \\
\text { identified }\end{array}$ \\
\hline $\begin{array}{l}\text { Grabenbauer } \\
\text { et al }\end{array}$ & 1998 & $\mathrm{MiBI}$ & 62 & $\boxplus \mathrm{HC}$ & $\begin{array}{l}62 \text { chemo- } \\
\text { radiotherapy }\end{array}$ & 0 & (52) & $34 \%$ & $\begin{array}{l}73 \text { vs } 50 \% \\
5 \text {-year DFS }\end{array}$ & $\begin{array}{l}\text { Higher } \mathrm{MiBI} \text { index associated } \\
\text { with better colostomy-free } \\
\text { survival }(P=0.04)\end{array}$ \\
\hline $\begin{array}{l}\text { Indinnimeo } \\
\text { et al }\end{array}$ & $2000 a, b$ & $\mathrm{Ki}-67$ & 31 & $\Vdash H C$ & $\begin{array}{l}13 \text { chemo- } \\
\text { radiotherapy } \\
7 \text { radiotherapy } \\
\text { followed by } \\
\text { local excision }\end{array}$ & $\begin{array}{l}5 \text { local excision, } \\
6 \text { APR }\end{array}$ & 74.4 & $65 \%$ & Not reported & $\begin{array}{l}\text { No prognostic significance } \\
\text { identified }\end{array}$ \\
\hline Ajani et al & 2009 & Ki-67 & 30 & $\Vdash H C$ & $\begin{array}{l}30 \text { chemo- } \\
\text { radiotherapy }\end{array}$ & 0 & Not reported & Not reported & $\begin{array}{l}R R=0.98 \\
\text { for DFS }\end{array}$ & $\begin{array}{l}\text { Higher levels of Ki-67 associated } \\
\text { with longer DFS }(P=0.005)\end{array}$ \\
\hline $\begin{array}{l}\text { Grabenbauer } \\
\text { et al }\end{array}$ & 1998 & PCNA & 62 & $\Vdash H C$ & $\begin{array}{l}62 \text { chemo- } \\
\text { radiotherapy }\end{array}$ & 0 & $(52)$ & $32 \%$ & $\begin{array}{l}78 \text { vs } 45 \% \\
5 \text {-year DFS }\end{array}$ & $\begin{array}{l}\text { No prognostic significance } \\
\text { identified }\end{array}$ \\
\hline $\begin{array}{l}\text { Holm and } \\
\text { Tanum }\end{array}$ & 1996 & $\mathrm{~nm} 23$ & 96 & $\mathrm{HC}$ & $\begin{array}{l}96 \text { chemo- } \\
\text { radiotherapy }\end{array}$ & 0 & 60 & $79 \%$ & Not reported & $\begin{array}{l}\text { Cytoplasmic } \mathrm{nm} 23 \text { expression } \\
\text { associated with shorter survival } \\
P=0.03 \text { ) }\end{array}$ \\
\hline $\begin{array}{l}\text { Indinnimeo } \\
\text { et al }\end{array}$ & $2000 a, b$ & $\mathrm{~nm} 23$ & 22 & $\Vdash H C$ & $\begin{array}{l}9 \text { chemo- } \\
\text { radiotherapy } \\
5 \text { chemotherapy }\end{array}$ & $\begin{array}{l}2 \text { local excision } \\
6 \text { APR }\end{array}$ & 63.6 & $27 \%$ & Not reported & $\begin{array}{l}\text { No prognostic significance } \\
\text { identified }\end{array}$ \\
\hline Bruland et al & 2008 & MCM7 & 55 & $\mathrm{HC}$ & $\begin{array}{l}9 \text { radiotherapy } \\
\text { alone } \\
46 \text { chemo- } \\
\text { radiotherapy }\end{array}$ & 0 & 86.4 & Not reported & Not reported & $\begin{array}{l}\text { High MCM7 correlated with } \\
\text { improved cancer-specific survival } \\
(P=0.0 \mathrm{II})\end{array}$ \\
\hline $\begin{array}{l}\text { Holm and } \\
\text { Tanum }\end{array}$ & 1996 & Cathepsin D & 96 & $\mathrm{H} \mathrm{HC}$ & $\begin{array}{l}96 \text { chemo- } \\
\text { radiotherapy }\end{array}$ & 0 & 60 & $50 \%$ & Not reported & $\begin{array}{l}\text { No prognostic significance } \\
\text { identified }\end{array}$ \\
\hline
\end{tabular}

76 (79\%) showed cytoplasmic nm23 staining, with 23 of these cases also exhibiting positive nuclear staining (Holm and Tanum, 1996). A correlation was identified between the presence of cytoplasmic nm23 and shorter overall survival $(P=0.03)$, but no correlation was identified between nuclear nm 23 staining and survival using univariate analysis (Holm and Tanum, 1996). These results are contradictory with respect to its proposed function as a suppressor of metastasis (Holm and Tanum, 1996). A smaller Italian study of the H1subtype of the $\mathrm{nm} 23$ protein in 22 anal cancer patients found no significant association between $\mathrm{nm} 23 \mathrm{H} 1$ expression and prognosis (Indinnimeo et al, 2000a).

MCM7 MCM7 belongs to a family of 6 minichromosome maintenance proteins (MCM 2-7) that have an essential role in DNA replication and can be detected throughout the cell cycle. They are degraded in cells that have exited the cell cycle, such as fully differentiated cells (Tachibana et al, 2005). They have documented potential as cancer biomarkers capable of predicting outcome in squamous neoplasms of the oral cavity (Kodani et al, 2003). Bruland et al (2008) studied MCM7 in anal carcinoma and found that high levels of the MCM7 gene product was significantly associated with improved relapse-free survival $(P=0.017)$ and cancer-specific survival $(P=0.011)$ using univariate analysis (Table 6).

Cathepsin D Cathepsin D is a lysosomal hydrolase involved in proteolysis and is hypersecreted in neoplastic cells (Abbott et al, 2010). Excessive production of this protein in the tumour microenvironment promotes extracellular matrix degradation, thereby enhancing the invasive potential of cancerous cells (Abbott et al, 2010). Overexpression of Cathepsin D has been associated with poorer outcome in breast carcinoma (Niu et al, 2002; Brujan et al, 2009), although these findings have not consistently been replicated (Cocquyt et al, 2003; Anim et al, 2005).
A single study assessed the prognostic significance of Cathepsin D in anal cancer, and although $50 \%$ of tumours were Cathepsin D positive, the investigators found no correlation with overall survival $(P>0.10)$ or with the clinicopathological parameters of tumour stage, tumour differentiation or lymph node involvement (Table 6) (Holm and Tanum, 1996).

\section{Angiogenesis}

Vascular endothelial growth factor (VEGF) Neovascularisation is key to tumour invasion and metastasis, and VEGF has an important role in this angiogenic process through interaction with its complimentary VEGF receptors (Backer et al, 2009). Anticancer therapies have been developed that target the VEGF receptor in order to improve tumour response rates. Two studies have investigated the prognostic significance of tumour VEGF levels in anal cancer patients treated with chemoradiotherapy, but neither study identified a correlation with patient survival (Table 7) (Wong et al, 1999; Ajani et al, 2009).

Microvessel density (MVD) and cluster of differentiation 31 (CD31) In recent years, a widely established method of determining tumour vascularity has been through calculating MVD, which involves identifying vascular hot spots within the tumours and subsequently counting the number of individual microvessels seen (Pathak et al, 2008). MVD can thus be considered as a semiquantitative marker of angiogenesis. A number of endothelial surface markers have been used to examine MVD in malignant tumours, and among the three studies that have assessed the prognostic significance of MVD in anal cancer, one study used factor VIII (Wong et al, 1999) and two studies used the CD31 molecule (Table 7) (Indinnimeo et al, 2001; Nilsson et al, 2006). All three studies, however, failed to demonstrate a putative role for MVD in predicting anal cancer prognosis (Wong et al, 1999; Indinnimeo et al, 2001; Nilsson et al, 2006). 
Table 7 Studies of markers of angiogenesis in anal carcinoma

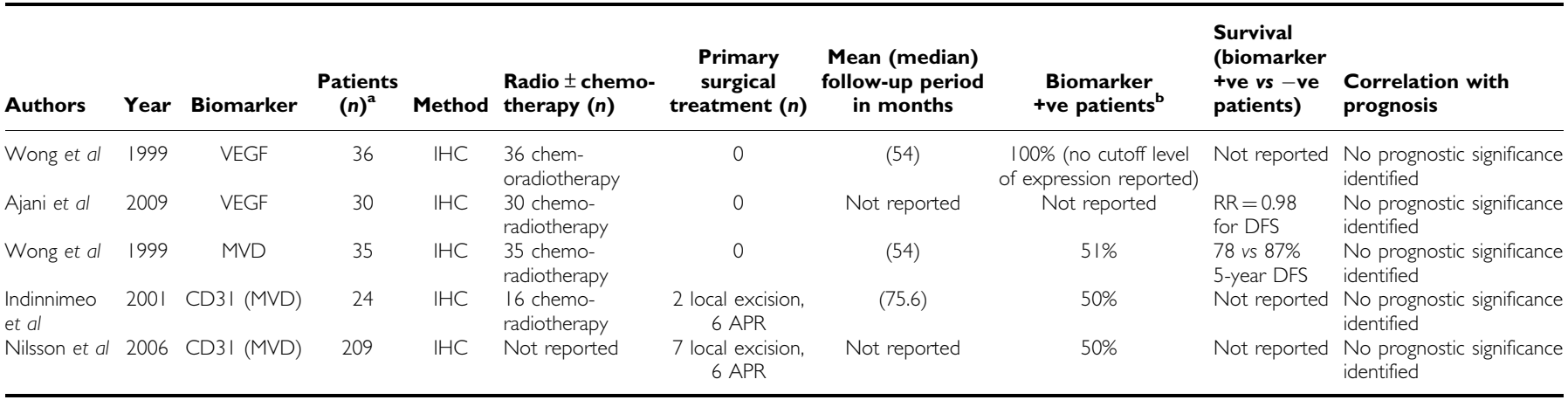

Abbreviations: $A P R=$ abdominoperineal resection; DFS = disease-free survival; $\| H C=$ immunohistochemistry; VEGF = vascular endothelial growth factor; $M V D=$ microvessel density; $\mathrm{CD} 3 \mathrm{I}=$ cluster of differentiation $3 \mathrm{I} ; \mathrm{RR}=$ relative risk. ${ }^{\mathrm{a}}$ Patients included in final biomarker analysis. ${ }^{\mathrm{b}}$ In studies where patients have been differentiated by the presence or absence of tumour biomarker overexpression, overexpression is considered as biomarker positive.

Table 8 Studies of tumour markers, hedgehog signalling and telomerase activity in anal carcinoma

\begin{tabular}{|c|c|c|c|c|c|c|c|c|c|c|}
\hline Authors & Year & $\begin{array}{l}\text { Bio- } \\
\text { marker }\end{array}$ & $\begin{array}{l}\text { Patients } \\
(n)^{\mathrm{a}}\end{array}$ & Method & $\begin{array}{l}\text { Radio } \pm \text { chemo- } \\
\text { therapy }(n)\end{array}$ & $\begin{array}{l}\text { Primary } \\
\text { surgical } \\
\text { treatment } \\
\text { (n) }\end{array}$ & $\begin{array}{l}\text { Mean (median) } \\
\text { follow-up } \\
\text { period } \\
\text { in months }\end{array}$ & $\begin{array}{l}\text { Biomarker } \\
\text { +ve patients }\end{array}$ & $\begin{array}{l}\text { Survival } \\
\text { (biomarker } \\
\text { +ve vs - ve } \\
\text { patients) }\end{array}$ & $\begin{array}{l}\text { Correlation with } \\
\text { prognosis }\end{array}$ \\
\hline Fontana et al & |99| & SCCAg & 66 & RIA & Not reported & Not reported & 42.4 & $54 \%$ & Not reported & $\begin{array}{l}\text { Correlation with relapse only in } \\
\text { post-treatment samples }\end{array}$ \\
\hline Goldman et al & 1993 & SCCAg & 60 & RIA & 59 radiotherapy & I APR & $(42)$ & $33 \%$ & $\begin{array}{l}43 \text { vs } 81 \% \\
5 \text {-year overall } \\
\text { survival }\end{array}$ & $\begin{array}{l}\text { Elevated } S C C A g \text { level correlated } \\
\text { with reduced overall survival } \\
(P=0.02) \text { and tumour-free } \\
\text { survival }(P<0.00005) \text {. }\end{array}$ \\
\hline Tanum et al & 1992 & CEA & 106 & $\begin{array}{l}\text { RIA and } \\
\text { tissue staining }\end{array}$ & $\begin{array}{l}106 \text { chemo- } \\
\text { radiotherapy }\end{array}$ & 0 & 65.2 & $19 \%$ & Not reported & $\begin{array}{l}\text { No prognostic significance } \\
\text { identified }\end{array}$ \\
\hline Ajani et al & 2009 & $\mathrm{SHH}$ & 30 & $\mathrm{HC}$ & $\begin{array}{l}30 \text { chemo- } \\
\text { radiotherapy }\end{array}$ & 0 & Not reported & Not reported & $\begin{array}{l}\mathrm{RR}=1.03 \\
\text { for DFS }\end{array}$ & $\begin{array}{l}\text { Higher levels of } \mathrm{SHH} \text { associated } \\
\text { with shorter DFS }(P=0.02)\end{array}$ \\
\hline Ajani et al & 2009 & Gli-I & 30 & $\mathrm{IHC}$ & $\begin{array}{l}30 \text { chemo- } \\
\text { radiotherapy }\end{array}$ & 0 & Not reported & Not reported & $\begin{array}{l}\mathrm{RR}=1.03 \\
\text { for DFS }\end{array}$ & $\begin{array}{l}\text { Higher levels of Gli-I associated } \\
\text { with shorter DFS }(P=0.02)\end{array}$ \\
\hline Ajani et al & 2009 & hTERT & 30 & $\mathrm{HC}$ & $\begin{array}{l}30 \text { chemo- } \\
\text { radiotherapy }\end{array}$ & 0 & Not reported & Not reported & $\begin{array}{l}R R=0.98 \\
\text { for DFS }\end{array}$ & $\begin{array}{l}\text { No prognostic significance } \\
\text { identified }\end{array}$ \\
\hline
\end{tabular}

Abbreviations: $\mathrm{APR}=$ abdominoperineal resection; $\mathrm{DFS}=$ disease-free survival; $\mathrm{RAI}=$ radioimmunoassay; $\mathrm{SCCAg}=$ squamous cell carcinoma antigen; $\mathrm{CEA}=$ carcinoembryonic

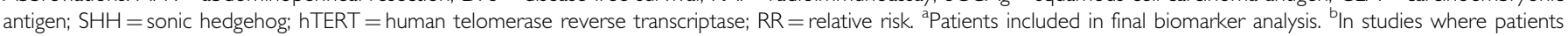
have been differentiated by the presence or absence of tumour biomarker overexpression, overexpression is considered as biomarker positive.

The study by Indinnimeo et al (2001) did however report a positive correlation between CD31 score and depth of tumour invasion $(P<0.05)$ in anal cancer, which supports the hypothesis that tumour growth occurs through angiogenesis-dependent mechanisms.

\section{Tumour markers}

SCC antigen (SSCAg) Serum concentrations of SCCAg, a polypeptide subunit of a protein originally identified in malignant human cervical tissue (Kato and Torigoe, 1977), is elevated in several tumour sites including the anal canal (Petrelli et al, 1988; Indinnimeo et al, 1997). Goldman et al (1993) examined the prognostic significance of this tumour marker and reported a clear association between SCCAg levels and survival (Table 8). Higher pretreatment serum SCCAg levels correlated with reduced tumourfree survival $(P<0.00005)$ and overall survival $(P=0.02)$ using multivariate analysis (Goldman et al, 1993). Another study of SCCAg in anal cancer found no prognostic value of pretreatment serum SCCAg, but did note that SCCAg levels were significantly elevated in patients who had relapsed following primary treatment (Fontana et al, 1991).

Carcinoembryonic antigen (CEA) CEA, a complex glycoprotein that has long been established as a useful adjunct in monitoring patients with colorectal cancer (Goldstein and Mitchell, 2005), was investigated over a decade ago in patients with anal SCC undergoing combined chemoradiotherapy (Table 8) (Tanum et al, 1992). Of the patients, $19 \%$ were found to have raised serum CEA levels before treatment and $17.5 \%$ of tumours stained positive for CEA, but no correlation with clinical outcome was observed (Tanum et al, 1992).

\section{Sonic hedgehog (SHH) signalling}

SHH and Gli-1 Sonic hedgehog is a secreted glycoprotein belonging to the hedgehog family of proteins that are essential to organogenesis (Ruiz i Altaba et al, 2002). SHH triggers a complex signal transduction pathway, the cellular response to which is mediated by three Gli proteins (Gli-1, Gli-2 and Gli-3) (Ruiz i Altaba et al, 2002). Gli-1 is a transcription factor that serves as an important regulator of mammalian hedgehog signalling (Ruiz i Altaba et al, 2002). Hedgehog signalling has been associated with failure to respond to chemoradiotherapy and also with increased incidence of tumour regrowth following treatment.

Ajani et al (2009) investigated the prognostic role in patients with anal cancer treated with chemoradiotherapy. Immunohistochemistry was used to measure tumour SHH and Gli-1 expression. Overexpression of both markers was demonstrated through multivariate analysis to be independent predictors of shorter DFS ( $P=0.02$ and $P=0.02$, respectively; Table 8$)$. 
Human telomerase reverse transcriptase (hTERT) Tumour proliferation and invasion is dependent on the activity of the telomerase enzyme that is responsible for extension of chromosomal ends (Deville et al, 2009). The hTERT protein forms a subunit of telomerase, and high levels of expression have been reported in several human malignancies including lung, bladder, oesophagus and colorectal tumours (de Kok et al, 2000). One study of hTERT in anal cancer failed to identify a relationship between expression of protein and patient outcome (Table 8) (Ajani et al, 2009).

\section{DISCUSSION}

Outcomes from the studies summarised in this review highlight a spectrum of biomarkers in anal cancer that may predict patient response to chemoradiation. Tumour-suppressor genes $p 53$ and $p 21$ have been shown to be of potential prognostic value in patients with anal cancer treated by chemoradiation, although these findings were not found to be universal. The discordant findings may at least in part, be explained by methodological differences such as the choice of detection antibodies used in the immunohistochemical analysis. The reliability of immunostaining in detection of p53 mutation remains uncertain, thereby affecting detection rates and subsequent clinical correlation (Neal et al, 2006). Mutational analysis using sequencing techniques has also been used for p53 detection in human cancers, but these techniques have not been employed in prognostic studies of anal carcinoma to date (Neal et al, 2006). Although clarification of the role of p53 and p21 is required in patients treated with chemoradiotherapy, further evaluation of their potential as novel therapeutic targets is also essential. Although not yet assessed in anal SCC, clinical trials of treatment of oesophageal SCC with adenovirus-mediated p53 gene transfer in combination with radiotherapy has been associated with improved local tumour control in unresectable tumours (Oohira et al, 2004). Simultaneous vector-mediated transduction of both p53 and p21 mRNA into hepatocellular and colorectal carcinoma cells performed in a recent study (Idogawa et al,2009) was shown to increase rates of apoptotic cell death and also act synergistically with doxorubicin, thus having important therapeutic implications.

Since the establishment and effective use of trastuzumab (HER-2) in the treatment of breast carcinoma, there has been a drive to target the EGFR family of receptor proteins in other human cancers. None of these studies of EGFR in anal cancer have identified a direct link between EGFR status and prognosis after chemoradiation. However, the high levels of EGFR expression seen in anal tumours suggest that trials to investigate the activity of both TK inhibition and antibody inhibition of EGFR signalling are merited. It remains to be elucidated whether EGFR copy number (Hirsch et al, 2006) and EGFR mutation status (Zhu et al, 2008) will be markers of response to these agents in the context of anal SCC as has been shown for lung cancers. There are likely to be additional factors involved in determining patient responsiveness to these agents. The $K-R A S$ gene, encoding a protein downstream of the EGFR receptor, has been associated with poorer responses to EGFR inhibitors when present in a mutated form. In the setting of colorectal cancer, it appears active only in colorectal cancers harbouring wild-type K-RAS (Amado et al, 2008). Recent data (Bonner et al, 2010) from a randomised trial of 424 patients with head and neck SCC revealed that survival was prolonged when anti-EGFR therapy (cetuximab) was combined with radiotherapy compared with radiotherapy alone. Clearly, other potential markers of response, such as B-RAF status, require assessment in this context. This also appears predominantly a 'K-RAS wildtype' disease according to a single small study (Zampino et al, 2009).
A single preliminary study suggested that NF- $\kappa \mathrm{B}$ may be of prognostic value in anal cancer, but there have not been any other confirmatory studies (Ajani et al, 2009). Studies of NF- $\kappa \mathrm{B}$, most notably haematological malignancies, demonstrate that aberrant expression of this transcription factor is associated with tumour growth, progression and resistance to chemotherapeutic agents (Baud and Karin, 2009). Moreover, the use of the reversible 26S proteosome inhibitor bortezomib, which inhibits NF- $\kappa \mathrm{B}$ activity, is an effective and approved agent in the treatment of multiple myeloma (Baud and Karin, 2009). However, NF- $\kappa$ B-targeted therapy is yet to become as widely established in other human malignancies.

Other apoptotic regulators that were shown to correlate with anal cancer prognosis in a single study were the Bcl-2 and M30 proteins (Allal et al, 2003). Two other studies of Bcl-2 failed to identify a correlation with clinical outcome (Le et al, 2005; Ajani et al, 2009). These studies had a relatively small patient sample size and therefore the true prognostic impact of the Bcl-2 and other apoptoticregulatory molecules may need larger cohorts. In the study of apoptosis-regulating proteins by Allal et al (2003), subgroup analysis revealed that patients with Bcl-2-positive/p53-negative anal tumours had significantly higher 5-year DFS compared with patients with tumours expressing all other combinations of these two proteins. Furthermore, results from phase III trials of oblimerson (Genasense), an antisense nucleotide that targets Bcl-2, in chronic lymphocytic leukaemia showed improved survival rates only when given in conjunction with conventional chemotherapy but not when used alone (O'Brien et al, 2007). This suggests that future therapeutic targets may need to be used in conjunction with cytotoxic agents or other targeted treatments.

Data from two of the four studies of $\mathrm{Ki}-67 / \mathrm{MiB} 1$ supported a predictive role in the prognosis of anal cancer patients treated with chemoradiotherapy (Grabenbauer et al, 1998; Ajani et al, 2009). In these studies, high Ki-67/MiB1 positivity correlated with improved survival that may be related to heightened responses to antiproliferative chemotherapeutic agents. This is highlighted by the fact that in the two studies where no prognostic significance was found, there were a cohort of patients who were not treated with chemotherapy but received radiotherapy (with or without local excision) (Allal et al, 1998; Indinnimeo et al, 2000b). The question therefore remains as to whether the potential prognostic value of $\mathrm{Ki}-67 / \mathrm{MiB} 1$ is confined to certain treatment groups and if individuals with highly proliferative tumours as determined by their $\mathrm{Ki}-67 / \mathrm{MiB} 1$ index are likely to require more aggressive treatment regimens.

The oncological significance of the VEGF molecule is evident from the established use bevacizumab (Avastin), a humanised anti-VEGF monoclonal antibody in the treatment of metastatic breast, colorectal, renal and non-small cell lung carcinoma (Goerner et al, 2010). The two studies of VEGF in anal cancer reported no association with patient outcome (Wong et al, 1999; Ajani et al, 2009). The prognostic significance of VEGF in anal carcinoma needs further evaluation.

Investigation of molecular markers such as p16, PCNA, MVD and the $\mathrm{Rb}$ protein failed to demonstrate a prognostic utility in anal cancer. However, the degree to which these findings are limited by methodological factors is unclear. Other proteins such as M30, cyclin A, SCCAg, SHH and Gli-1 were demonstrated to be of predictive value in individual studies but further trials are required to reproduce these findings.

Other cancers related to HPV infection continue to increase in incidence. HPV-associated head and neck SCC is associated with HPV 16 similar to anogenital SCCs. In situ hybridisation studies have demonstrated that HPV status correlates (Kuo et al, 2008) with treatment response, progression-free survival and overall survival in oropharyngeal SCC (Fakhry et al, 2008; Ang et al, 2010). In this setting, much debate exists regarding the optimal detection technique and whether P-16 should be used as a surrogate marker. 
Future strategies may involve the application of such hypotheses to anal cancer with the potential for vaccine therapy in established HPV-associated disease. The National Cancer Institute Phase II trial has completed accrual in studying the effectiveness of human papillomavirus vaccine (HPV-16 E-6 and E-7 peptides) therapy in treating patients who have advanced or recurrent cancer of the cervix, vagina, penis, anus, oesophagus, or head and neck (National Cancer Institute, 2009). We await the results of these and other studies.

There is a growing appreciation of the fact that all clinical trials of emerging targeted treatments must incorporate biomarkers studies in order to minimise the possibility of failing to appreciate significant activity of the drug in a biological subset of a given cancer type and to maximise the chance of response in a given patient. This is all the more essential in the case of anal carcinoma, which is an uncommon cancer type that will limit the patient numbers available for clinical trials. Certainly, there are targeted treatments that have been shown to have activity in other EGFR-expressing cancers that need assessment in this tumour type, and biomarkers that have been shown to be helpful in other cancer sites should be prioritised for assessment. Any biomarker studies and validation thereof should aim to comply with Biomarker Task Force recommendations in order to ensure that results can be assessed in terms of realistic clinical utility (Dancey et al, 2010).

\section{CONCLUSION}

Biomarkers in anal cancer may possess the ability to tailor treatment to individuals. Certain markers such as the EGFR protein are potential treatment targets in this disease. It remains to be seen if biomarkers of response to anti-EGFR therapies shown to be of use in other carcinoma types are applicable to anal carcinoma. Larger prospective studies of single or panels of multiple biomarkers are necessary with standardised methodology. Novel study designs are required and future prospects include the use of DNA microarray-based gene expression profiling that has already been shown to provide valuable prognostic information in patients with breast cancer (Munkacsy et al, 2010). Pharmacogenomics has the potential to make a major contribution to biomarker identification and future directions of therapy in anal cancer. Within its realm, single-nucleotide polymorphism (SNP) analysis serves as a promising avenue for future research studies. Although the quest for prognostic markers in anal cancer is currently in its early stages, expanding research into this field is driven by the prospect of unravelling molecular characteristics of these tumours that may ultimately prolong patient survival and reduce the health and economic burden of this disease epidemic.

\section{REFERENCES}

Abbott DE, Margaryan NV, Jeruss JS, Khan S, Kaklamani V, Winchester D, Hansen N, Rademaker A, Khalkhali-Ellis Z, Hendrix MJ (2010) Reevaluating cathepsin D as a biomarker for breast cancer: serum activity levels versus histopathology. Cancer Biol Ther 9(1): 23-30

Ajani JA, Wang X, Izzo JG, Crane CH, Eng C, Skibber JM, Das P, Rashid A (2009) Molecular biomarkers correlate with disease-free survival in patients with anal canal carcinoma treated with chemoradiation. Dig Dis Sci 55: $1098-1105$

Allal AS, Alonso-Pentzke L, Remadi S (1998) Apparent lack of prognostic value of MIB-1 index in anal carcinomas treated by radiotherapy. Br J Cancer 77(8): 1333 - 1336

Allal AS, Gervaz P, Brundler MA (2004) Cyclin D1, cyclin E, and p21 have no apparent prognostic value in anal carcinomas treated by radiotherapy with or without chemotherapy. Br J Cancer 91(7): 1239-1244

Allal AS, Waelchli L, Brundler MA (2003) Prognostic value of apoptosisregulating protein expression in anal squamous cell carcinoma. Clin Cancer Res 9(17): 6489-6496

Alvarez G, Perry A, Tan BR, Wang HL (2006) Expression of epidermal growth factor receptor in squamous cell carcinomas of the anal canal is independent of gene amplification. Mod Pathol 19(7): $942-949$

Amado RG, Wolf M, Peeters M, Van Cutsem E, Siena S, Freeman DJ, Juan T, Sikorski R, Suggs S, Radinsky R, Patterson SD, Chang DD (2008) Wild-type KRAS is required for panitumumab efficacy in patients with metastatic colorectal cancer. J Clin Oncol 26(10): 1626-1634

Ang KK, Harris J, Wheeler R, Weber R, Rosenthal DI, Nguyen-Tan PF, Westra WH, Chung CH, Jordan RC, Lu C, Kim H, Axelrod R, Silverman CC, Redmond KP, Gillison ML (2010) Human papillomavirus and survival of patients with oropharyngeal cancer. $N$ Engl J Med 363: 24-35

Anim JT, John B, Abdulsathar SS, Prasad A, Saji T, Akhtar N, Ali V, Al-Saleh M (2005) Relationship between the expression of various markers and prognostic factors in breast cancer. Acta Histochem 107(2): 87-93

Backer MV, Hamby CV, Backer JM (2009) Inhibition of vascular endothelial growth factor receptor signaling in angiogenic tumor vasculature. Adv Genet 67: 1-27

Bartek J, Lukas J (2001) Pathways governing G1/S transition and their response to DNA damage. FEBS Lett 490(3): 117-122

Baud V, Karin M (2009) Is NF-kappaB a good target for cancer therapy? Hopes and pitfalls. Nat Rev Drug Discov 8(1): 33-40

Bonin SR, Pajak TF, Russell AH, Coia LR, Paris KJ, Flam MS, Sauter ER (1999) Overexpression of p53 protein and outcome of patients treated with chemoradiation for carcinoma of the anal canal: a report of randomized trial RTOG 87-04. Radiation Therapy Oncology Group. Cancer 85(6): 1226-1233
Bonner JA, Harari PM, Giralt J, Cohen RB, Jones CU, Sur RK, Raben D, Baselga J, Spencer SA, Zhu J, Youssoufian H, Rowinsky EK, Ang KK (2010) Radiotherapy plus cetuximab for locoregionally advanced head and neck cancer: 5-year survival data from a phase 3 randomised trial, and relation between cetuximab-induced rash and survival. Lancet Oncol 11(1): $21-28$

Bourgo RJ, Braden WA, Wells SI, Knudsen ES (2009) Activation of the retinoblastoma tumor suppressor mediates cell cycle inhibition and cell death in specific cervical cancer cell lines. Mol Carcinog 48(1): $45-55$

Brujan I, Margaritescu C, Simionescu C, Pirici D, Fronie A, Foarfa C, Stepan A, Vrabete M (2009) Cathepsin-D expression in breast lesion: an immunohistochemical study. Rom J Morphol Embryol 50(1): 31 - 39

Bruland O, Fluge O, Immervoll H, Balteskard L, Myklebust M, Skarstein A, Dahl O (2008) Gene expression reveals two distinct groups of anal carcinomas with clinical implications. Br J Cancer 98(7): 1264-1273

Carr NJ (2000) M30 expression demonstrates apoptotic cells, correlates with in situ end-labeling, and is associated with $\mathrm{Ki}-67$ expression in large intestinal neoplasms. Arch Pathol Lab Med 124(12): 1768-1772

Coate LE, John T, Tsao MS, Shepherd FA (2009) Molecular predictive and prognostic markers in non-small-cell lung cancer. Lancet Oncol 10(10): $1001-1010$

Cocquyt VF, Schelfhout VR, Blondeel PN, Depypere HT, Daems KK, Serreyn RF, Praet MM, Van Belle SJ (2003) The role of biological markers as predictors of response to preoperative chemotherapy in large primary breast cancer. Med Oncol 20(3): 221-231

Crook T, Wrede D, Tidy J, Scholefield J, Crawford L, Vousden KH (1991) Status of c-myc, p53 and retinoblastoma genes in human papillomavirus positive and negative squamous cell carcinomas of the anus. Oncogene 6(7): $1251-1257$

Cummings BJ (2006) Metastatic anal cancer: the search for cure. Onkologie 29(1-2): 5-6

Dancey JE, Dobbin KK, Groshen S, Jessup JM, Hruszkewycz AH, Koehler M, Parchment R, Ratain MJ, Shankar LK, Stadler WM, True LD, Gravell A, Grever MR (2010) Guidelines for the development and incorporation of biomarker studies in early clinical trials of novel agents. Clin Cancer Res 16(6): $1745-1755$

Das P, Crane CH, Eng C, Ajani JA (2008) Prognostic factors for squamous cell cancer of the anal canal. Gastrointest Cancer Res 2(1): 10-14

de Kok JB, Ruers TJ, van Muijen GN, van Bokhoven A, Willems HL, Swinkels DW (2000) Real-time quantification of human telomerase reverse transcriptase mRNA in tumors and healthy tissues. Clin Chem 46(3): $313-318$ 
Deville L, Hillion J, Segal-Bendirdjian E (2009) Telomerase regulation in hematological cancers: a matter of stemness? Biochim Biophys Acta 1792(4): $229-239$

Du W, Searle JS (2009) The rb pathway and cancer therapeutics. Curr Drug Targets 10(7): $581-589$

el-Deiry WS, Tokino T, Velculescu VE, Levy DB, Parsons R, Trent JM, Lin D, Mercer WE, Kinzler KW, Vogelstein B (1993) WAF1, a potential mediator of p53 tumor suppression. Cell 75(4): 817-825

Fakhry C, Westra WH, Cmelak SLA, Ridge JA, Pinto H, Forastiere A, Gillison ML (2008) Improved survival of patients with human papillomavirus-positive head and neck squamous cell carcinoma in a prospective clinical trial. J Natl Cancer I 100(4): 261-269

Finlay CA, Hinds PW, Levine AJ (1989) The p53 proto-oncogene can act as a suppressor of transformation. Cell 57(7): 1083-1093

Fontana X, Lagrange JL, Francois E, Bourry J, Chauvel P, Sordage M, Lapalus F, Namer M (1991) Assessment of 'squamous cell carcinoma antigen' (SCC) as a marker of epidermoid carcinoma of the anal canal. Dis Colon Rectum 34(2): 126-131

Gerdes J, Schwab U, Lemke H, Stein H (1983) Production of a mouse monoclonal antibody reactive with a human nuclear antigen associated with cell proliferation. Int J Cancer 31(1): 13-20

Goerner M, Seiwert TY, Sudhoff H (2010) Molecular targeted therapies in head and neck cancer - An update of recent developments. Head Neck Oncol 2(1): 8

Goldman S, Svensson C, Bronnergard M, Glimelius B, Wallin G (1993) Prognostic significance of serum concentration of squamous cell carcinoma antigen in anal epidermoid carcinoma. Int $J$ Colorectal Dis 8(2): $98-102$

Goldstein MJ, Mitchell EP (2005) Carcinoembryonic antigen in the staging and follow-up of patients with colorectal cancer. Cancer Invest 23(4): $338-351$

Grabenbauer GG, Matzel KE, Schneider IH, Meyer M, Wittekind C, Matsche B, Hohenberger W, Sauer R (1998) Sphincter preservation with chemoradiation in anal canal carcinoma: abdominoperineal resection in selected cases? Dis Colon Rectum 41(4): $441-450$

Harper JW, Adami GR, Wei N, Keyomarsi K, Elledge SJ (1993) The p21 Cdk-interacting protein Cip1 is a potent inhibitor of G1 cyclindependent kinases. Cell 75(4): 805-816

Hirsch FR, Varella-Garcia M, Bunn Jr PA, Franklin WA, Dziadziuszko R, Thatcher N, Chang A, Parikh P, Pereira JR, Ciuleanu T, von Pawel J, Watkins C, Flannery A, Ellison G, Donald E, Knight L, Parums D, Botwood N, Holloway B (2006) Molecular predictors of outcome with gefitinib in a phase III placebo-controlled study in advanced non-smallcell lung cancer. J Clin Oncol 24(31): 5034-5042

Holm R, Skovlund E, Skomedal H, Florenes VA, Tanum G (2001) Reduced expression of p21WAF1 is an indicator of malignant behaviour in anal carcinomas. Histopathology 39(1): 43-49

Holm R, Tanum G (1996) Evaluation of the prognostic significance of nm23/NDP kinase and cathepsin D in anal carcinomas. An immunohistochemical study. Virchows Arch 428(2): 85-89

Idogawa M, Sasaki Y, Suzuki H, Mita H, Imai K, Shinomura Y, Tokino T (2009) A single recombinant adenovirus expressing p53 and p21targeting artificial microRNAs efficiently induces apoptosis in human cancer cells. Clin Cancer Res 15(11): 3725-3732

Indinnimeo M, Cicchini C, Stazi A, Giarnieri E, French D, Limiti MR, Ghini C, Vecchione A (1999) Human papillomavirus infection and p53 nuclear overexpression in anal canal carcinoma. J Exp Clin Cancer Res 18(1): $47-52$

Indinnimeo $\mathrm{M}$, Cicchini $\mathrm{C}$, Stazi A, Giarnieri E, Limiti MR, Ghini C, Vecchione A (2000a) nm23-H1 protein expression in anal canal carcinoma: does it correlate with prognosis? J Surg Oncol 74(2): 163-166

Indinnimeo M, Cicchini C, Stazi A, Limiti MR, Ghini C, Mingazzini P, Vecchione A (2000b) Immunohistochemical assessment of Ki-67 as prognostic cellular proliferation marker in anal canal carcinoma. J Exp Clin Cancer Res 19(4): 471-475

Indinnimeo $\mathrm{M}$, Cicchini $\mathrm{C}$, Stazi A, Limiti MR, Ghini C, Mingazzini PL, Vecchione A (2001) Prognostic impact of CD31 antigen expression in anal canal carcinoma. Hepatogastroenterology 48(41): 1355-1358

Indinnimeo M, Reale MG, Cicchini C, Stazi A, Fiori E, Izzo P (1997) CEA, TPA, CA 19-9, SCC and CYFRA at diagnosis and in the follow-up of anal canal tumors. Int Surg 82(3): 275-279

Kastan MB, Canman CE, Leonard CJ (1995) P53, cell cycle control and apoptosis: implications for cancer. Cancer Metastasis Rev 14(1): $3-15$

Kato H, Torigoe T (1977) Radioimmunoassay for tumor antigen of human cervical squamous cell carcinoma. Cancer 40(4): 1621-1628
Kodani I, Osaki M, Shomori K, Araki K, Goto E, Ryoke K, Ito H (2003) Minichromosome maintenance 2 expression is correlated with mode of invasion and prognosis in oral squamous cell carcinomas. J Oral Pathol Med 32(8): $468-474$

Komiya T, Hosono Y, Hirashima T, Masuda N, Yasumitsu T, Nakagawa K, Kikui M, Ohno A, Fukuoka M, Kawase I (1997) p21 expression as a predictor for favorable prognosis in squamous cell carcinoma of the lung. Clin Cancer Res 3(10): $1831-1835$

Kuo KT, Hsiao CH, Lin CH, Kuo LT, Huang SH, Lin MC (2008) The biomarkers of human papillomavirus infection in tonsillar squamous cell carcinoma-molecular basis and predicting favorable outcome. Mod Pathol 21(4): 376-386

Le LH, Chetty R, Moore MJ (2005) Epidermal growth factor receptor expression in anal canal carcinoma. Am J Clin Pathol 124(1): 20-23

Lowe SW, Lin AW (2000) Apoptosis in cancer. Carcinogenesis 21(3): $485-495$

MacDonald NJ, de la Rosa A, Steeg PS (1995) The potential roles of nm23 in cancer metastasis and cellular differentiation. Eur J Cancer $31 \mathrm{~A}(7-8)$ : $1096-1100$

Madhusudan S, Ganesan TS (2004) Tyrosine kinase inhibitors in cancer therapy. Clin Biochem 37(7): 618-635

Mammas IN, Sourvinos G, Giannoudis A, Spandidos DA (2008) Human papilloma virus (HPV) and host cellular interactions. Pathol Oncol Res 14(4): $345-354$

Munkacsy G, Abdul-Ghani R, Mihaly Z, Tegze B, Tchernitsa O, Surowiak P, Schafer R, Gyorffy B (2010) PSMB7 is associated with anthracycline resistance and is a prognostic biomarker in breast cancer. Br J Cancer 102(2): $361-368$

National Cancer Institute (2009) Vaccine therapy and detection of immunologic responses with human papillomavirus 16 E6 and E7 peptides in patients with metastatic or locally advanced cancer. www.clinicaltrials.gov/ct2/show/NCT00019110

Naugler WE, Karin M (2008) NF-kappaB and cancer-identifying targets and mechanisms. Curr Opin Genet Dev 18(1): 19-26

Neal CP, Garcea G, Doucas H, Manson MM, Sutton CD, Dennison AR, Berry DP (2006) Molecular prognostic markers in resectable colorectal liver metastases: a systematic review. Eur J Cancer 42(12): 1728-1743

Nigro ND, Vaitkevicius VK, Considine Jr B (1974) Combined therapy for cancer of the anal canal: a preliminary report. Dis Colon Rectum 17(3): $354-356$

Nilsson PJ, Lenander C, Rubio C, Auer G, Ljungqvist O, Glimelius B (2006) Prognostic significance of Cyclin A in epidermoid anal cancer. Oncol Rep 16(3): $443-449$

Niu Y, Fu X, Lv A, Fan Y, Wang Y (2002) Potential markers predicting distant metastasis in axillary node-negative breast carcinoma. Int $J$ Cancer 98(5): 754-760

O'Brien S, Moore JO, Boyd TE, Larratt LM, Skotnicki A, Koziner B, Chanan-Khan AA, Seymour JF, Bociek RG, Pavletic S, Rai KR (2007) Randomized phase III trial of fludarabine plus cyclophosphamide with or without oblimersen sodium (Bcl-2 antisense) in patients with relapsed or refractory chronic lymphocytic leukemia. J Clin Oncol 25(9): $1114-1120$

Oldenhuis CN, Oosting SF, Gietema JA, de Vries EG (2008) Prognostic versus predictive value of biomarkers in oncology. Eur J Cancer 44(7): 946-953

Oohira G, Yamada S, Ochiai T, Matsubara H, Okazumi S, Ando K, Tsujii H, Hiwasa T, Shimada H (2004) Growth suppression of esophageal squamous cell carcinoma induced by heavy carbon-ion beams combined with p53 gene transfer. Int J Oncol 25(3): 563-569

Pagano M, Pepperkok R, Verde F, Ansorge W, Draetta G (1992) Cyclin A is required at two points in the human cell cycle. EMBO J 11(3): 961-971

Palefsky JM, Holly EA, Efirdc JT, Da Costa M, Jay N, Berry JM, Darragh TM (2005) Anal intraepithelial neoplasia in the highly active antiretroviral therapy era among HIV-positive men who have sex with men. AIDS 19(13): $1407-1414$

Pathak AP, Hochfeld WE, Goodman SL, Pepper MS (2008) Circulating and imaging markers for angiogenesis. Angiogenesis 11(4): 321-335

Paz-Ares L, Sanchez JM, Garcia-Velasco A, Massuti B, Lopez-Vivanco G, Provencio M, Montes A, Isla D, Amador ML, Rosell R, Grp SLC (2006) A prospective phase II trial of erlotinib in advanced non-small cell lung cancer (NSCLC) patients (p) with mutations in the tyrosine kinase (TK) domain of the epidermal growth factor receptor (EGFR). J Clin Oncol 24(18s): 7020

Petrelli NJ, Shaw N, Bhargava A, Daufeldt J, Herrera L, Stulc JP, Sischy B, Mittelman A (1988) Squamous cell carcinoma antigen as a marker 
for squamous cell carcinoma of the anal canal. J Clin Oncol 6(5): $782-785$

Place RJ, Gregorcyk SG, Huber PJ, Simmang CL (2001) Outcome analysis of HIV-positive patients with anal squamous cell carcinoma. Dis Colon Rectum 44(4): $506-512$

Roninson IB (2002) Oncogenic functions of tumour suppressor p21(Waf1/Cip1/Sdi1): association with cell senescence and tumourpromoting activities of stromal fibroblasts. Cancer Lett 179(1): $1-14$

Rousseau Jr DL, Thomas Jr CR, Petrelli NJ, Kahlenberg MS (2005) Squamous cell carcinoma of the anal canal. Surg Oncol 14(3): 121-132

Ruiz i Altaba A, Palma V, Dahmane N (2002) Hedgehog-Gli signalling and the growth of the brain. Nat Rev Neurosci 3(1): 24-33

Shalhoub J, Naughton P, Lau N, Tsang JS, Kelly CJ, Leahy AL, Cheshire NJ, Darzi AW, Ziprin P (2009) Concurrent colorectal malignancy and abdominal aortic aneurysm: a multicentre experience and review of the literature. Eur J Vasc Endovasc Surg 37(5): 544-556

Shea BJ, Grimshaw JM, Wells GA, Boers M, Andersson N, Hamel C, Porter AC, Tugwell P, Moher D, Bouter LM (2007) Development of AMSTAR: a measurement tool to assess the methodological quality of systematic reviews. BMC Med Res Methodol 7: 10

Shi W, Kato H, Perez-Ordonez B, Pintilie M, Huang S, Hui A, O'Sullivan B, Waldron J, Cummings B, Kim J, Ringash J, Dawson LA, Gullane P, Siu L, Gillison M, Liu FF (2009) Comparative prognostic value of HPV16 E6 mRNA compared with in situ hybridization for human oropharyngeal squamous carcinoma. J Clin Oncol 27(36): $6213-6221$

Shin DM, Hittelman WN, Hong WK (1994) Biomarkers in upper aerodigestive tract tumorigenesis: a review. Cancer Epidemiol Biomarkers Prev 3(8): $697-709$

Siddiqui AD, Piperdi B (2009) KRAS mutation in colon cancer: a marker of resistance to EGFR-I therapy. Ann Surg Oncol 17: 1168-1176
Sturm I, Petrowsky H, Volz R, Lorenz M, Radetzki S, Hillebrand T, Wolff G, Hauptmann S, Dorken B, Daniel PT (2001) Analysis of p53/BAX/ p16(ink4a/CDKN2) in esophageal squamous cell carcinoma: high BAX and p16(ink4a/CDKN2) identifies patients with good prognosis. J Clin Oncol 19(8): 2272-2281

Tachibana KE, Gonzalez MA, Coleman N (2005) Cell-cycle-dependent regulation of DNA replication and its relevance to cancer pathology. $J$ Pathol 205(2): $123-129$

Tanum G, Holm R (1996) Anal carcinoma: a clinical approach to p53 and RB gene proteins. Oncology 53(5): 369-373

Tanum G, Stenwig AE, Bormer OP, Tveit KM (1992) Carcinoembryonic antigen in anal carcinoma. Acta Oncol 31(3): 333-335

Treish I, Schwartz R, Lindley C (2000) Pharmacology and therapeutic use of trastuzumab in breast cancer. Am J Health Syst Pharm 57(22): 2063 - 2076; quiz 2077-9

UKCCCR Anal Cancer Trial Working Party (1996) Epidermoid anal cancer: results from the UKCCCR randomised trial of radiotherapy alone versus radiotherapy, 5-fluorouracil, and mitomycin. Lancet 348(9034): 1049- 1054

Vogelstein B, Lane D, Levine AJ (2000) Surfing the p53 network. Nature 408(6810): $307-310$

Wong CS, Tsao MS, Sharma V, Chapman WB, Pintilie M, Cummings BJ (1999) Prognostic role of p53 protein expression in epidermoid carcinoma of the anal canal. Int J Radiat Oncol Biol Phys 45(2): 309-314

Zampino MG, Magni E, Sonzogni A, Renne G (2009) K-ras status in squamous cell anal carcinoma (SCC): it's time for target-oriented treatment? Cancer Chemother Pharmacol 65(1): 197-199

Zhu CQ, da Cunha Santos G, Ding K, Sakurada A, Cutz JC, Liu N, Zhang T, Marrano P, Whitehead M, Squire JA, Kamel-Reid S, Seymour L, Shepherd FA, Tsao MS (2008) Role of KRAS and EGFR as biomarkers of response to erlotinib in National Cancer Institute of Canada Clinical Trials Group Study BR.21. J Clin Oncol 26(26): 4268-4275 